\title{
Retinoid Protection against X-ray-induced Chromatid Damage in Human Peripheral Blood Lymphocytes
}

\author{
Katherine K. Sanford, * Ram Parshad, ` Floyd M. Price, " Robert E. Tarone, ${ }^{3}$ and Kenneth H. Kraemer" \\ ${ }^{*}$ Laboratory of Cellular and Molecular Biology, National Cancer Institute, Bethesda, Maryland 20892; ${ }^{\circledR D e p a r t m e n t ~ o f ~ P a t h o l o g y, ~}$ \\ Howard University College of Medicine, Washington, DC 20059; \$iostatistics Branch, National Cancer Institute, Bethesda, \\ Maryland 20892; and "Laboratory of Molecular Carcinogenesis, National Cancer Institute, Bethesda, Maryland 20892
}

\begin{abstract}
Oral administration of isotretinoin (13-cis retinoic acid) was shown previously (Kraemer, K. H., J. J. DiGiovanna, A. N. Moshell, R. E. Tarone, and G. L. Peck. 1988. N. Engl. J. Med. 318:1633-1637) to reduce the frequency of skin cancers in xeroderma pigmentosum (XP) patients. The mechanism of protection was unclear. In the present study, $x$-ray-induced chromatid damage in PHA-stimulated blood lymphocytes from five XP patients receiving isotretinoin was approximately half that in blood samples from the same patients before or subsequent to treatment. The $x$-ray-induced chromatid damage in blood lymphocytes from a normal control was reduced significantly by cocultivation with blood or plasma from an XP patient receiving isotretinoin or by addition of $10^{-6} \mathrm{M}$ isotretinoin to cultures $1 \mathrm{~h}$ before $x$-irradiation. A similar reduction in $x$-ray-induced chromatid damage was reported previously by adding to the culture medium, mannitol, a scavenger of the free hydroxyl radical, or catalase, which decomposes hydrogen peroxide; both of these products are generated during ionizing radiation. The present observations suggest that isotretinoin acts as a scavenger of such radiation products, thereby providing protection against x-ray-induced chromatid damage. (J. Clin. Invest. 1992. 90:2069-2074.) Key words: xeroderma pigmentosum • isotretinoin • oxidative DNA damage $\bullet$ skin cancer $\cdot$ cytogenetics
\end{abstract}

\section{Introduction}

Retinoids comprise a group of compounds including retinoic acid, retinol ( vitamin A), retinaldehyde, and a series of natural and synthetic derivatives that exert diverse and profound effects on proliferation and differentiation in a wide variety of cell, tissue, and organ systems (1-3). Certain retinoids such as all-trans and 13-cis-retinoic acid (isotretinoin) are inhibitors of epidermal promotion by phorbol esters in the two stage (initiation-promotion) model of skin carcinogenesis $(4,5)$. Because of their inhibitory effects on carcinogenesis in rodent and human tissues both in vivo and in culture $(6,7)$, retinoids have been used in recent years as possible anticancer chemopreventive agents, particularly against cutaneous $(8,9)$ and internal (bladder, leukemia, aerodigestive tract) neoplasms (for review see references 3 and 10 ).

An abstract for a poster presentation of this paper has been published in 1991 (Proc. Am. Assoc. Cancer Res. 32:21).

Address reprint requests to Dr. Katherine K. Sanford, Building 37, Room 2D15, National Cancer Institute, Bethesda, MD 20892.

Received for publication 12 March 1992 and in revised form 19 May 1992.

The Journal of Clinical Investigation, Inc.

Volume 90, November 1992, 2069-2074
One such clinical study was carried out on xeroderma pigmentosum $(\mathrm{XP})^{1}$ patients (11). XP is a rare autosomal recessive disease characterized by sun sensitivity, deficient repair of ultraviolet-damaged DNA, and a frequency of skin cancer $>1,000$ times that in the general population $(12,13)$. In the 3-yr clinical study, five XP patients with a history of multiple cutaneous basal-cell or squamous-cell carcinomas were treated with isotretinoin (11). Oral administration of the drug at a dosage of $2 \mathrm{mg} / \mathrm{kg}$ body wt per $\mathrm{d}$ for $2 \mathrm{yr}$ resulted in an average reduction of $63 \%$ in skin cancers. After the drug was discontinued, the tumor frequency increased a mean of 8.5 -fold over the frequency during treatment. Within 2 mo of the onset of therapy, tumor incidence decreased whereas tumors appeared within 3 mo after withdrawal of treatment.

To examine possible mechanisms for this chemopreventive effect, we evaluated the radiosensitivity and DNA repair capacity of blood lymphocytes taken from certain of these XP patients before, during, or after isotretinoin therapy. The extent of chromatid damage in metaphase cells arrested by colcemid during the first $30 \mathrm{~min}$ after $\mathrm{x}$-irradiation during the $\mathrm{G}_{2}$ phase of the cell cycle provides a measure of the cells' susceptibility to the damaging agent or radiosensitivity. The persistence, increase, or decrease in frequencies of chromatid breaks and gaps during the subsequent 1-2 h provides a measure of the cells' capacity to repair the radiation-induced damage. XP cells show persistent chromatid breaks and gaps relative to normal controls (14-16). We also studied the x-ray-induced chromatid breakage in normal cells after preincubation with blood or plasma from isotretinoin-treated patients or with medium supplemented with isotretinoin. Exposure to isotretinoin resulted in substantial reduction of $\mathrm{x}$-ray-induced chromatid breakage.

\section{Methods}

Patients. We studied five XP patients who were participating in a study to assess prevention of skin cancer with the use of oral isotretinoin (11). Patients are identified as in reference 11. There were three females and two males ranging in age from 5 to $19 \mathrm{yr}$ at the beginning of the study. The patients had from 6 to $>200$ skin cancers before treatment. Patients received oral isotretinoin capsules (Accutane; Roche Laboratories; Nutley, $\mathrm{NJ})$ continuously at either high dose $(2 \mathrm{mg} / \mathrm{kg}$ per d) or low dose ( $0.5 \mathrm{mg} / \mathrm{kg}$ per d) as described (11). Blood samples were obtained when patients had received treatment for $1 \mathrm{wk}$ to $17 \mathrm{mo}$ or during periods when the patients had not received isotretinoin for $\geq 1 \mathrm{mo}$ (range: $1 \mathrm{mo}$ to $6 \mathrm{yr}$ ). Nine clinically normal hospital or laboratory staff members ( two females and seven males, age 30-72 yr) served as control donors (15).

Experimental procedure. Freshly drawn blood $(3.5 \mathrm{ml})$ was added to a T-25 flask containing $35 \mathrm{ml}$ of RPMI 1640 medium with $15 \%$ prescreened FBS (14), $10 \mathrm{U}$ of heparin $/ \mathrm{ml}, 0.1 \mathrm{mg}$ of gentamicin $/ \mathrm{ml}$,

1. Abbreviation used in this paper: XP, xeroderma pigmentosum. 


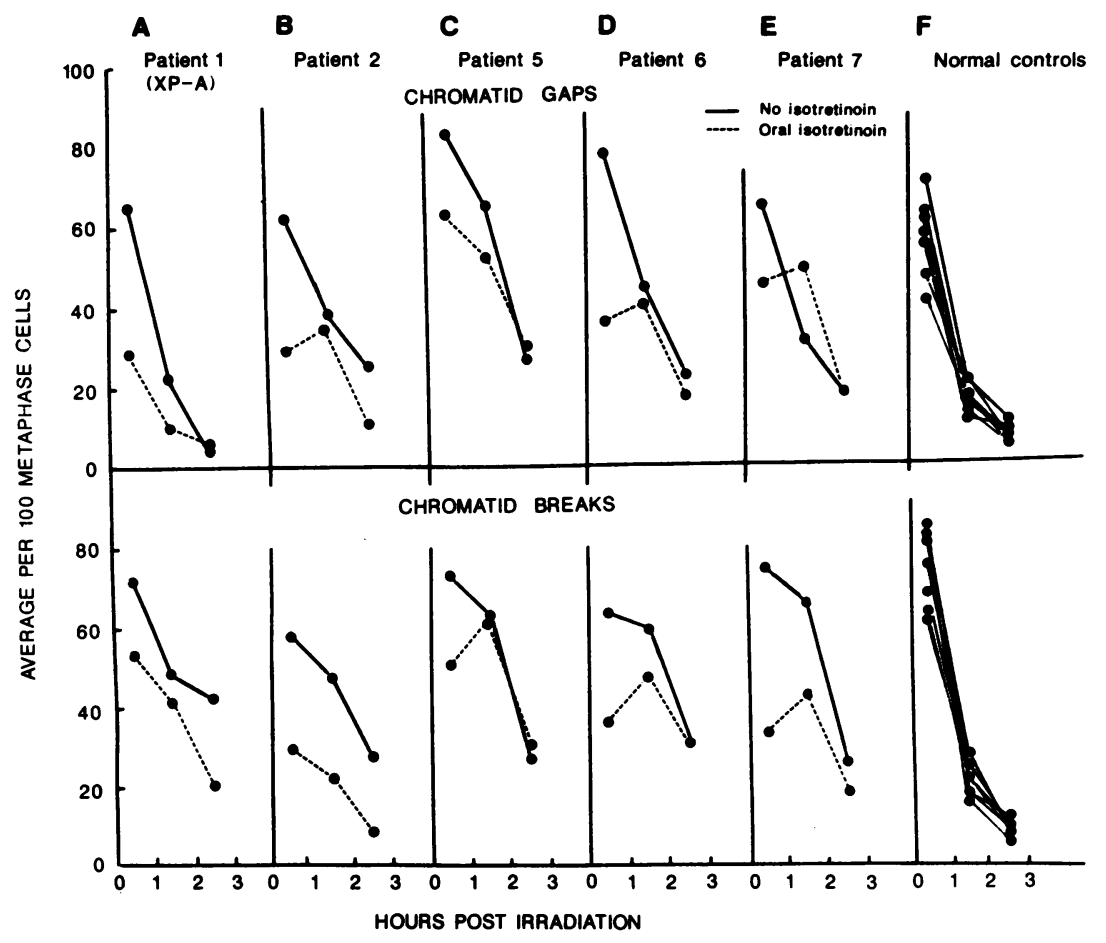

Figure 1. Effect of presence or absence of oral isotretinoin on response of PHA-stimulated blood lymphocytes to $\mathrm{x}$-irradiation (58R) during $\mathrm{G}_{2}$ phase of the cell cycle. $(A-E)$ Five XP patients with or without retinoid treatment; $(F)$ nine clinically normal donors without retinoid treatment (from reference 15). Cultures of PHA-stimulated peripheral blood lymphocytes were exposed to $x$ rays during the $G_{2}$ phase of the cell cycle. Synchronization of cells for $G_{2}$ phase was unnecessary because only metaphase cells were examined for chromatid damage and these were arrested with colcemid from 0 to $0.5,0.5$ to 1.5 , or 1.5 to 2.5 $\mathrm{h}$ after irradiation; therefore, we could be assured that the cells processed at 1.5 and $2.5 \mathrm{~h}$ postirradiation were in $\mathrm{G}_{2}$ at the time of irradiation. Slide cultures were randomized and coded for chromosome analyses performed blind. For each variable, 50 or 100 metaphase cells were examined at $\times 1,000$. Chromatid breaks showed a discontinuity with displacement of the broken segment whereas gaps showed no displacement and were scored only if the discontinuity was longer than the chromatid width; these are sometimes referred to as nondisplaced breaks. All standard errors were $<10 \%$ of the mean. and 1\% (vol/vol) PHA (HA 15, Burroughs-Wellcome, Research Triangle Park, NC). The medium was equilibrated with $10 \% \mathrm{CO}_{2}$ in air to adjust the $\mathrm{pH}$ and was warmed at $37^{\circ} \mathrm{C}$ before addition of the blood sample. The culture was incubated upright for $72 \mathrm{~h}$ before $\mathrm{x}$-irradiation and inverted every $24 \mathrm{~h}$ to resuspend cells. The procedure for $\mathrm{x}$-irradiating the cells, incubating with colcemid to arrest cells in metaphase, and processing for chromosome analysis has been fully detailed (17). For in vitro studies, a fresh stock of pure isotretinoin (Sigma Chemical Co., St. Louis, MO) was diluted with DMSO and $50 \mu \mathrm{l}$ was added to each culture containing $6.6 \mathrm{ml}$ blood diluted $1: 10$ with culture medium and $0.2 \mathrm{ml}$ plasma from a normal control. The final concentration of DMSO was thus $0.73 \%$ in the culture medium. $1 \mathrm{~h}$ exposure of cells to isotretinoin before $\mathrm{x}$-irradiation did not include the time required for pelleting the cells ( $10 \mathrm{~min}$ ) and $x$-irradiation $(67 \mathrm{~s})$. Cytogenetic analyses were made on randomized, coded preparations. Statistical comparisons were based on the $t$ test after taking square root transformation of the aberration frequency; two-sided $P$ values are reported (18).

\section{Results}

Effect of oral isotretinoin on response of XP lymphocytes to $G_{2}$ phase $x$-irradiation. Fig. $1, A-E$ presents the effect of the presence or absence of oral isotretinoin on responses of PHA-stimulated blood lymphocytes from five XP patients, identified previously by number (11) and Fig. $1 F$ shows the responses of PHA-stimulated lymphocytes from nine clinically normal controls without isotretinoin, as reported previously (15). The initial $x$-ray-induced chromatid damage during isotretinoin treatment of the XP patients was reduced to approximately half that in blood samples taken from the same patients before or subsequent to treatment ( $P=0.003$ for chromatid breaks; $P=0.006$ for gaps). Compared with cells from normal controls (Fig. 1 $F$ ), retinoid-treated XP cells showed significantly fewer chromatid aberrations when arrested during the first $0.5 \mathrm{~h}$ postirradiation ( $P=10^{-4}$ for breaks and $P=10^{-3}$ for gaps).

XP cells without retinoid treatment processed at 1.5 to 2.5 $h$ postirradiation showed 2.9- and 3.8-fold higher mean fre- quencies of persistent chromatid breaks and gaps than cells from clinically normal controls $\left(P<10^{-6}\right.$ except for gaps in $\mathrm{XP}-\mathrm{A}$, as described in reference 15). However, XP cells with retinoid treatment still maintained a significantly higher than normal frequency of aberrations at 1.5 and $2.5 \mathrm{~h}$ postirradiation $\left(P=8 \times 10^{-4}\right.$ for breaks and $P=0.008$ for gaps at $1.5 \mathrm{~h} ; P$ $=2 \times 10^{-3}$ for breaks and $P=0.028$ for gaps at $2.5 \mathrm{~h}$ ). Thus, oral isotretinoin appeared to protect the cells from the initial radiation-induced DNA damage. It did not, however, eliminate the DNA repair deficiency manifest as persistent chromatid breaks and gaps after $G_{2}$ phase x-irradiation.

Response of normal lymphocytes to blood or plasma from isotretinoin-treated XP patients. We next sought to determine if this radioprotective effect could be transferred to normal cells by mixing normal cells with blood from a retinoid-treated XP patient. Table I shows that PHA-stimulated lymphocytes from an isotretinoin-treated XP female patient had 40 breaks and 32 gaps after G2 x-irradiation (culture 1) whereas blood from a clinically normal male had 76 breaks and 60 gaps (culture 2). Incubation of the blood from the normal male for $72 \mathrm{~h}$ with the blood from the XP female resulted in significantly fewer chromatid aberrations ( 41 breaks, $P=0.03$ and 30 gaps, $P=0.005$ ) in the male metaphases (culture 3 ). This protection was not seen when the normal male blood was incubated with blood from a normal female not receiving isotretinoin (culture 4). Thus, the radioprotective effect of isotretinoin-containing blood could be transferred.

The next series of experiments were designed to determine if the radioprotection found in whole blood required cells or only the plasma (Table II). Blood from a normal donor was incubated with plasma from a retinoid-treated XP patient for $72 \mathrm{~h}$ and then $\mathrm{x}$-irradiated. The mean frequency of breaks and gaps per 100 cells of normal lymphocytes was not reduced with addition of $0.9 \%$ plasma but was reduced from 128 to 59 with concentrations of plasma of 1.5 to $8.3 \%$ added $72 \mathrm{~h}$ before irradiation. Only a short exposure was necessary since even $1 \mathrm{~h}$ 
Table I. Reduction in X-ray-induced Chromatid Damage by $72 \mathrm{~h}$ Incubation of Normal Blood Lymphocytes with Blood from Isotretinoin-treated XP Patient

\begin{tabular}{|c|c|c|c|c|c|}
\hline \multirow[b]{2}{*}{$\begin{array}{l}\text { Culture } \\
\text { no. }\end{array}$} & \multicolumn{3}{|c|}{$\begin{array}{l}\text { Blood samples* in } 20 \mathrm{ml} \\
\text { RPMI } 1640+15 \% \text { FBS }\end{array}$} & \multicolumn{2}{|c|}{$\begin{array}{l}\text { Chromatid damage per } \\
100 \text { metaphase cells }\end{array}$} \\
\hline & $\begin{array}{c}\text { Treated } \\
\text { XP female }\end{array}$ & $\begin{array}{l}\text { Normal } \\
\text { male }\end{array}$ & $\begin{array}{l}\text { Normal } \\
\text { female }\end{array}$ & $\begin{array}{l}\text { Breaks } \\
\text { (gender) }\end{array}$ & $\begin{array}{c}\text { Gaps } \\
\text { (gender) }\end{array}$ \\
\hline & & $m l$ & & & \\
\hline 1 & 2 & 0 & 0 & $40(F)$ & $32(\mathrm{~F})$ \\
\hline 2 & 0 & 2 & 0 & $76(M)$ & $60(\mathrm{M})$ \\
\hline \multirow[t]{2}{*}{3} & 1 & 1 & 0 & $41(\mathrm{M})$ & $30(\mathrm{M})$ \\
\hline & & & & $33(F)$ & $32(F)$ \\
\hline \multirow[t]{2}{*}{4} & 0 & 1 & 1 & $76(\mathrm{M})$ & $72(\mathrm{M})$ \\
\hline & & & & $70(F)$ & $64(F)$ \\
\hline
\end{tabular}

* Volume of blood sample from indicated donor added to $20 \mathrm{ml}$ RPMI 1640 medium containing 15\% FBS and incubated for $72 \mathrm{~h}$ before $\mathrm{x}$-irradiation (58R). Metaphase cells were arrested by colcemid from 0 to $0.5 \mathrm{~h}$ postirradiation. For details see Methods and reference 17.

‡ Patient 2, receiving low-dose oral isotretinoin $(0.5 \mathrm{mg} / \mathrm{kg}$ per $\mathrm{d})$.

${ }^{8} \mathrm{~F}$, female; $\mathrm{M}$, male.

exposure reduced the $x$-ray-induced chromatid damage approximately one half. These experiments showed that plasma alone from isotretinoin-treated XP patients could confer radiation protection to normal blood lymphocytes after either $72 \mathrm{~h}$ or $1 \mathrm{~h}$ incubation at $37^{\circ} \mathrm{C}$ before irradiation.

Effect of isotretinoin on response of normal lymphocytes to $G_{2}$ phase x-irradiation. Plasma from isotretinoin-treated XP patients contains isotretinoin and its metabolites. We next wanted to determine if the radioprotective effect could be duplicated by exposure to therapeutic concentrations of isotretinoin. In two additional experiments (Table III), isotretinoin in DMSO added $1 \mathrm{~h}$ before $\mathrm{x}$-irradiation to $72 \mathrm{~h}$ cultures of PHAstimulated normal blood reduced the frequencies of x-ray-induced chromatid breaks and gaps to approximately half that in control culture. This reduction in frequency of chromatid breaks and gaps was similar to that found by addition of plasma from the isotretinoin-treated XP patient. At concentrations of isotretinoin of $10^{-9}$ to $10^{-6} \mathrm{M}$, no dose response was apparent, but $10^{-5} \mathrm{M}$ showed a greater degree of radioprotection. Addition of isotretinoin immediately after $\mathrm{x}$-irradiation had no effect on the radiation-induced chromatid damage. This observation suggests that the radioprotective effect acts during $\mathrm{x}$ irradiation.

\section{Discussion}

Cultures of PHA-stimulated peripheral blood lymphocytes exposed to x-rays during the $G_{2}$ phase of the cell cycle show chromatid damage at the subsequent metaphase. The damage consists of breaks and gaps (for definitions see legend Fig. 1). Because each chromatid contains a single continuous molecule of double-stranded DNA, chromatid breaks and gaps represent unrepaired DNA strand breaks. These may arise directly from the $\mathrm{x}$-irradiation (i.e., primary damage or secondary production of free radicals) or indirectly during repair processes (19).

In a previous study (15), the frequencies of chromatid breaks and gaps in blood lymphocytes from XP patients were
Table II. Effect of Added Plasma on Chromatid Damage Induced by $G_{2}$ Phase X-irradiation

\begin{tabular}{|c|c|c|c|c|c|}
\hline \multirow{3}{*}{$\begin{array}{l}\text { Status of } \\
\text { blood donor }\end{array}$} & \multicolumn{2}{|c|}{ Addition of plasma } & \multirow{3}{*}{$\begin{array}{c}\text { Duration of } \\
\text { incubation } \\
\text { with added } \\
\text { plasma }^{\ddagger}\end{array}$} & \multirow{2}{*}{\multicolumn{2}{|c|}{$\begin{array}{c}\text { Chromatid } \\
\text { damage per } \\
100 \text { cells }\end{array}$}} \\
\hline & \multirow[b]{2}{*}{ Source* } & \multirow{2}{*}{$\begin{array}{l}\text { Percent } \\
\text { plasma } \\
\text { added }\end{array}$} & & & \\
\hline & & & & Breaks & Gap \\
\hline & & & $h$ & & \\
\hline Normal & - & 0 & - & 75 & 66 \\
\hline Normal & - & 0 & - & 70 & 53 \\
\hline Normal & - & 0 & - & 68 & 51 \\
\hline Normal & Normal & 2.9 & 72 & 78 & 66 \\
\hline Normal & Normal & 2.9 & 1 & 70 & 62 \\
\hline Normal & XP-Retinoid & 0.9 & 72 & 91 & 82 \\
\hline Normal & XP-Retinoid & 1.5 & 72 & 25 & 29 \\
\hline Normal & XP-Retinoid & 1.5 & 72 & 28 & 25 \\
\hline Normal & XP-Retinoid & 1.5 & 72 & 28 & 27 \\
\hline Normal & XP-Retinoid & 2.9 & 72 & 31 & 34 \\
\hline Normal & XP-Retinoid & 2.9 & 72 & 29 & 27 \\
\hline Normal & XP-Retinoid & 2.9 & 72 & 27 & 29 \\
\hline Normal & XP-Retinoid & 8.3 & 72 & 39 & 37 \\
\hline Normal & XP-Retinoid & 1.5 & 1 & 33 & 30 \\
\hline Normal & XP-Retinoid & 2.9 & 1 & 24 & 22 \\
\hline XP & - & 0 & - & 60 & 56 \\
\hline $\mathbf{X P}$ & XP-Retinoid & 1.5 & 1 & 34 & 33 \\
\hline XP & XP-Retinoid & 2.9 & 1 & 37 & 39 \\
\hline XP-Retinoid & - & 0 & - & 32 & 32 \\
\hline XP-Retinoid & - & 0 & - & 26 & 22 \\
\hline
\end{tabular}

* Plasma from XP patients 2, 6, or 7 (reference 11) receiving oral isotretinoin $(2 \mathrm{mg} / \mathrm{kg}$ per $\mathrm{d})$.

${ }^{\ddagger}$ Cells obtained from the indicated donor were incubated at $37^{\circ} \mathrm{C}$ in $20 \mathrm{ml}$ RPMI 1640 medium containing 15\% FBS for $72 \mathrm{~h}$ before $\mathrm{x}$-irradiation (58R). The cultures were supplemented with the indicated amount of plasma from a normal donor or from a retinoidtreated XP patient for $72 \mathrm{~h}$ or for $1 \mathrm{~h}$ preceding $\mathrm{X}$-irradiation. Metaphase cells were arrested by colcemid for $0.5 \mathrm{~h}$ immediately after $\mathrm{x}$-irradiation. Results from four experiments are shown. Details in Methods.

found to be abnormally high in metaphase cells harvested at 1.5 or $2.5 \mathrm{~h}$ after $\mathrm{x}$-irradiation (58R). However, in cells harvested at the first $0.5 \mathrm{~h}$ after $\mathrm{x}$-irradiation, the levels were generally comparable to those in cells from clinically normal controls. The frequencies in normal cells decreased precipitously during the subsequent hour, presumably from efficient repair of the radiation-induced DNA damage. In contrast, the breaks and gaps persisted in the cells from XP patients. These results suggested that XP patients have a deficiency in repair of $\mathrm{X}$-rayinduced DNA damage inflicted during $G_{2}$ phase. A comparable abnormality was found in XP cells exposed during $G_{2}$ phase to visible light ( $405 \mathrm{~nm}$ wavelength) (16). A similar $\mathrm{G}_{2}$-phase deficiency has been reported in cells from all of the other cancer-prone genetic disorders examined to date. These include ataxia-telangiectasia, Bloom syndrome, familial polyposis coli, Gardner syndrome, Fanconi anemia, dysplastic nevus syndrome, hereditary cutaneous malignant melanoma, Wilms tumor, retinoblastoma, and dyskeratosis congenita (14, 20-27).

Our present experimental studies showed that blood cells from XP patients receiving oral isotretinoin therapy exhibited fewer chromatid breaks and gaps during the first $0.5 \mathrm{~h}$ after $\mathrm{G}_{2}$ 
Table III. X-ray-induced Chromatid Damage in Blood Lymphocytes from a Normal Donor after 1 h Incubation with 13-cis-Retinoic Acid

\begin{tabular}{|c|c|c|c|c|}
\hline \multirow[b]{3}{*}{ Treatment* } & \multicolumn{4}{|c|}{ Chromatid damage per 100 cells } \\
\hline & \multicolumn{2}{|c|}{ Experiment 1} & \multicolumn{2}{|c|}{ Experiment 2} \\
\hline & Breaks & Gaps & Breaks & Gaps \\
\hline None & 75 & 58 & 83 & 76 \\
\hline XP-retinoid ${ }^{\ddagger}$ plasma $(2.9 \%)$ & 29 & 26 & 31 & 32 \\
\hline \multicolumn{5}{|c|}{$\begin{array}{l}\text { 13-cis retinoic acid in DMSO added } \\
1 \mathrm{~h} \text { before } \mathrm{x} \text {-irradiation }\end{array}$} \\
\hline $10^{-9} \mathrm{M}$ & - & - & 34 & 34 \\
\hline $10^{-8} \mathrm{M}$ & 31 & 33 & 47 & 41 \\
\hline $10^{-7} \mathrm{M}$ & 30 & 28 & - & - \\
\hline $10^{-6} \mathrm{M}$ & 32 & 32 & - & 一 \\
\hline $10^{-5} \mathrm{M}$ & - & - & 24 & 24 \\
\hline Solvent control ( $0.73 \%$ DMSO) & 75 & 64 & 94 & 83 \\
\hline $\begin{array}{l}\text { 13-cis retinoic acid } 10^{-8} \mathrm{M} \text { in } \\
\text { DMSO added immediately } \\
\text { after } \mathrm{x} \text {-irradiation }\end{array}$ & 82 & 74 & - & - \\
\hline
\end{tabular}

* Cells from a normal donor were incubated for $72 \mathrm{~h}$ and then the culture medium was supplemented by the indicated treatment for 1 $\mathrm{h}$ preceding $\mathrm{x}$-irradiation (58R). Metaphase cells were arrested by exposure to colcemid for $0.5 \mathrm{~h}$ immediately after $\mathrm{x}$-irradiation. Details in Methods.

₹ Patient 2 receiving oral isotretinoin $(1 \mathrm{mg} / \mathrm{kg}$ per $\mathrm{d})$.

phase $\mathrm{x}$-irradiation than cells from the same individuals when they did not receive retinoids (Fig. $1 A-E$ ). With isotretinoin, despite lower initial chromatid damage, the XP cells still showed the persistent chromatid damage (Fig. 1, $A-E$ ). Thus, the retinoid effect appeared to be a specific reduction in initial $x$-ray damage without altering the DNA repair deficiency.

Oral isotretinoin is metabolized by the liver to several undefined products $(28,29)$. In addition, patients receiving oral isotretinoin experience numerous side effects, including alterations in liver function and in levels of circulating triglycerides. We performed a series of experiments to determine if the radioprotective effect was linked to these alterations. Experiments mixing normal blood with XP retinoid blood indicated that the radioprotective effect could be transferred (Table I). Mixing normal blood with plasma from an isotretinoin-treated XP patient indicated that the protective activity resided in the plasma (Table II). Although the patient received the retinoid continuously (shortest treatment period tested was $1 \mathrm{wk}$ ), only $1 \mathrm{~h}$ exposure to plasma was sufficient to protect the normal cells. Addition of pure isotretinoin to the normal cells for $1 \mathrm{~h}$ before $\mathrm{x}$-irradiation also provided protection. Blood levels of isotretinoin have been measured at $5 \times 10^{-7} \mathrm{M}(29)$. Addition of $10^{-7}-10^{-8} \mathrm{M}$ isotretinoin (Table III) provided similar radioprotection as patient plasma (Tables II and III), a result indicating that a major portion of the protection can be attributed to the parent compound. Addition of retinoid after $x$-ray exposure showed no protection, thus demonstrating that retinoid action occurs during $\mathrm{x}$-ray exposure. We showed previously (30) that radiation-induced chromatid damage, in the form of breaks and gaps, can be prevented to a large extent by adding to the culture medium mannitol, a scavenger of the free hydroxyl radical $\left({ }^{\circ} \mathrm{OH}\right)$ or catalase, an enzyme that decomposes hydrogen peroxide $\left(\mathrm{H}_{2} \mathrm{O}_{2}\right)(31)$; both of these products are formed during ionizing radiation $(32,33)$. Thus $\left({ }^{\circ} \mathrm{OH}\right)$ and $\mathrm{H}_{2} \mathrm{O}_{2}$ appear to be indirect or direct causative agents in the radiation-induced damage. These observations suggest that isotretinoin may act as a scavenger of the $\mathrm{H}_{2} \mathrm{O}_{2}$ or $\left({ }^{\circ} \mathrm{OH}\right)$ radicals generated during ionizing radiation, thereby providing protection against $\mathrm{x}$-ray-induced chromatid damage.

Several studies indicate that retinoids exert some of their effects as antioxidants or as scavengers of hydroperoxide or peroxyl radicals of oxygen (34-42). Retinoids were shown to inhibit superoxide $\left(\mathrm{O}_{2}^{-}\right)$radical production by human polymorphonuclear leukocytes stimulated with different phorbol ester promoters $(34,35)$; to inhibit ascorbic acid-induced lipid peroxidation in rat brain mitochondria (37); and to inhibit ascorbate-dependent, iron-catalyzed microsomal lipid peroxidation (38-42).

In a clinical study of the XP patients we tested, oral isotretinoin was found to be effective in preventing the appearance of new skin cancers (11). Within 2 mo of the onset of therapy, tumor incidence decreased; tumors appeared within $3 \mathrm{mo}$ after withdrawal of treatment. The average time required from initial sun injury to the formation of a malignant skin tumor in XP patients is considered to be several years since the mean age at first skin cancer was 8 yr for $186 \mathrm{XP}$ patients with skin cancer (12). Although the mechanism of the preventive effect of isotretinoin is unclear, the speed with which the preventive effect could be switched on and off suggested a suppressive effect of the retinoid on proliferation or promotion of tumors at a late stage in their formation rather than an effect on initial mutational steps. Alternatively, retinoids may arrest the growth of existing malignant lesions too small to be recognized clinically (11). Retinoids have been shown to have a chemopreventive effect on several types of neoplasms, including those of skin, aerodigestive tract, and bladder, as well as leukemia (3, 10 ). All of these observations suggest that retinoids act as inhibitors of tumor promotion or progression.

Laboratory observations suggest that retinoids, as antipromoters, may have two different modes of action. One is the proposed hormone-type mechanism in which the retinoic acid binds to a specific intracellular receptor protein and is transported to the cell nucleus where it binds to chromatin and affects gene expression by some as yet unidentified mechanism $(1,3,43)$. Consistent with this view are observations that retinoids prevent induction of ornithine decarboxylase in mouse skin after promotion by phorbol ester treatment (44). They may also modulate activity of the key enzyme protein kinase $C$ $(3,45,46)$. The second mode of action is more direct as an antioxidant or scavenger of reactive products of oxygen that can damage DNA and promote tumor formation or contribute to tumor progression.

Free radicals of oxygen have been implicated as key mediators of promotion and progression in tumor formation (4752). Oxidants such as $\mathrm{O}_{2}^{-}, \mathrm{H}_{2} \mathrm{O}_{2}$ and $\left({ }^{\circ} \mathrm{OH}\right)$ are produced as byproducts of many normal aerobic metabolic processes (53, 54) and may produce a high level of oxidative damage to DNA. Even exposure to visible light in the near-ultraviolet generates $\mathrm{H}_{2} \mathrm{O}_{2}$ and $\left({ }^{\circ} \mathrm{OH}\right)$ in cultured human skin cells, producing chromatid DNA damage $(55,56)$ and stimulating proliferation $(57$, 58). An oxidative DNA damage rate, as measured by urinary excretion of DNA adducts, has been estimated by Ames and 
Gold $(59,60)$ as high as $10^{4}$ DNA hits/cell per $d$ for endogenous oxidants. Such oxidative adducts are presumably efficiently removed and DNA damage repaired in normal subjects. However, in an XP patient with deficient repair of DNA damage, such endogenous as well as exogenous oxidative agents may contribute to the continued promotion and/or appearance of new tumors. Oral isotretinoin therapy may so reduce the level of these DNA-damaging agents as to block the progression from premalignant to malignant growth or arrest the growth of existing malignant lesions too small to be recognized. Thus prevention of oxidative damage may play a role in retinoid-induced chemoprevention of skin cancers in XP patients.

\section{References}

1. Roberts, A. B., and M. B. Sporn. 1984. Cellular biology and biochemistry of the retinoids. In The Retinoids. Vol. 2, M. B. Sporn, A. B. Roberts, and D. S. Goodman, editors. Academic Press, Orlando, FL. 209-286.

2. Nugent, J., and S. Clark, editors. Retinoids, Differentiation and Disease. 1985. Ciba Found. Symp. 113:1-41, 77-116, 168-190.

3. Lippman, S. M., J. F. Kessler, and F. L. Meyskens, Jr. 1987. Retinoids as preventive and therapeutic anticancer agents: activity and prevention of skin carcinogenesis by vitamin $\mathrm{A}$ acid and its analogues (retinoids). Cancer Treat. Rep. 71:391-405.

4. Bollag, W. 1972. Prophylaxis of chemically induced benign and malignant epithelial tumors by vitamin A acid (retinoic acid). Eur. J. Cancer. 8:689-693.

5. Verma, A. K., and R. K. Boutwell. 1980. Inhibition of tumour promoterinduced mouse epidermal ornithine decarboxylase. In Polyamines in Biomedical Research. J. M. Gaugas, editor. Wiley, New York. 185-201.

6. Bollag, W. 1983. Vitamin A and retinoids: from nutrition to pharmacotherapy in dermatology and oncology. Lancet. 1:860-863.

7. Moon, R. C., D. L. McCormick, and R. G. Mehta. 1983. Inhibition of carcinogenesis by retinoids. Cancer Res. 43:2469-2475.

8. Peck, G. L. 1985. Therapy and prevention of skin cancer. In Retinoids: New Trends in Research and Therapy. J. H. Saurat, editor. Karger, Basel, Switzerland. 345-354.

9. Meyskens, F. L., Jr., E. Gilmartin, D. S. Alberts, N. S. Levine, R. Brooks, S. E. Salman, and E. A. Surwit. 1982. Activity of isotretinoin against squamous cell cancers and preneoplastic lesions. Cancer Treat. Rep. 66:1315-1319.

10. Lippman, S. M., and F. L. Meyskens, Jr. 1988. Retinoids as anticancer agents. In Nutrition, Growth and Cancer. G. P. Tryfiates, editor. Alan R. Liss, New York. 229-244.

11. Kraemer, K. H., J. J. DiGiovanna, A. N. Moshell, R. E. Tarone, and G. L. Peck. 1988. Prevention of skin cancer in xeroderma pigmentosum with the use of oral isotretinoin. N. Engl. J. Med. 318:1633-1637.

12. Kraemer, K. H., M. M. Lee, and J. Scotto. 1987. Xeroderma pigmentosum: cutaneous, ocular and neurologic abnormalities in 830 published cases. Arch. Dermatol. 123:241-250.

13. Kraemer, K. H., M. M. Lee, and J. Scotto. 1984. DNA repair protects against cutaneous and internal neoplasia: evidence from xeroderma pigmentosum. Carcinogenesis. 5:511-514.

14. Sanford, K. K., R. Parshad, R. Gantt, R. E. Tarone, G. M. Jones, and F. M. Price. 1989. Factors affecting and significance of $G_{2}$ chromatin radiosensitivity in predisposition to cancer. Int. J. Radiat. Biol. 55:963-981.

15. Parshad, R., K. K. Sanford, K. H. Kraemer, G. M. Jones, and R. E. Tarone. 1990. Carrier detection in xeroderma pigmentosum. J. Clin. Invest. 85:135-138.

16. Price, F. M., R. Parshad, R. E. Tarone, and K. K. Sanford. 1991. Radiation-induced chromatid aberrations in Cockayne syndrome and xeroderma pigmentosum group $\mathrm{C}$ fibroblasts in relation to cancer predisposition. Cancer. Genet. Cytogenet. 57:1-10.

17. Sanford, K. K., R. Parshad, F. M. Price, G. M. Jones, R. E. Tarone, L. Eierman, P. Hale, and T. A. Waldman. 1990. Enhanced chromatid damage in blood lymphocytes after $G_{2}$ phase $x$-irradiation, a marker of the ataxia telangiectasia gene. J. Natl. Cancer Inst. 82:1050-1054.

18. Snedecor, G. W., and W. G. Cochran. 1980. Statistical Methods. Iowa State University Press, Ames, IA. 208-213.

19. Hanawalt, P. C., P. K. Cooper, A. K. Ganesan, and C. A. Smith. 1979. DNA repair in bacteria and mammalian cells. Annu. Rev. Biochem. 48:783-836.

20. Parshad, R., K. K. Sanford, and G. M. Jones. 1983. Chromatid damage after $\mathrm{G}_{2} \mathrm{x}$-irradiation of cells from cancer-prone individuals implicates deficiency in DNA repair. Proc. Natl. Acad. Sci. USA. 80:5612-5616.

21. Parshad, R., K. K. Sanford, and G. M. Jones. 1985. Chromatid damage induced by fluorescent light during $G_{2}$ phase in normal and Gardner syndrome individuals: interpretation in terms of deficient DNA repair. Mutat. Res. 151:5763.

22. Hsu, T. C., L. M. Cherry, and N. A. Samaan. 1985. Differential mutagen susceptibility in cultured lymphocytes of normal individuals and cancer patients. Cancer Genet. Cytogenet. 17:307-313.

23. Parshad, R., K. K. Sanford, and G. M. Jones. 1985. Chromosomal radiosensitivity during the $\mathrm{G}_{2}$ cell cycle period of skin fibroblasts from individuals with familial cancer. Proc. Natl. Acad. Sci. USA. 82:5400-5403.

24. Gantt, R., R. Parshad, F. M. Price, and K. K. Sanford. 1986. Biochemical evidence for deficient DNA repair leading to enhanced $\mathrm{G}_{2}$ chromosomal radiosensitivity and susceptibility to cancer. Radiat. Res. 108:117-126.

25. Sanford, K. K., and R. Parshad. 1989. Detection of cancer-prone individuals using cytogenetic response to $\mathrm{x}$-rays. In Chromosomal Aberrations: Basic and Applied Aspects. G. Obe and A. T. Natarajan, editors. Springer-Verlag, Berlin/Heidelberg. 113-120.

26. Takai, S., F. M. Price, K. K. Sanford, R. E. Tarone, and R. Parshad. 1990. Persistence of chromatid damage after $\mathrm{G}_{2}$ phase $\mathrm{x}$-irradiation in lymphoblastoid cells from Gardner's syndrome. Carcinogenesis. 11:1425-1428.

27. DeBauche, D. M., G. S. Pai, and W. S. Stanley. 1990. Enhanced G chromatid radiosensitivity in dyskeratosis congenita fibroblasts. Am. J. Hum Genet. 46:350-357.

28. Meyskens, F. L., Jr., G. E. Goodman, and D. S. Alberts. 1985. 13-cis-retinoic acid: pharmacology, toxicology and clinical applications for the prevention and treatment of human cancer. Crit. Rev. Oncol. Hematol. 3:75-101.

29. Brazzell, R. K., and W. A. Colburn. 1982. Pharmacokinetics of the retinoids isotretinoin and etretinate. J. Am. Acad. Dermatol. 6:643-651.

30. Parshad, R., R. Gantt, K. K. Sanford, G. M. Jones, and R. E. Tarone. 1982. Repair of chromosome damage induced by $x$-irradiation during $G_{2}$ phase in a line of normal human fibroblasts and its malignant derivative. J. Natl. Cancer Inst. 69:404-414.

31. Henderson, B. W., and A. C. Miller. 1986. Chemical and biochemical aspects of superoxide radicals and related species of activated oxygen. Radiat. Res. 108:196-205.

32. Singh, A. 1982. Oxygen radicals, hydrogen peroxide and oxygen toxicity Can. J. Physiol. Pharmacol. 60:1330-1345.

33. Fridovich, I. In Free Radicals in Biology, W. A. Pryor, editor. Vol. 1. Academic Press, New York. 239-277.

34. Witz, G., B. D. Goldstein, M. Amoruso, D. S. Stone, and W. Troll. 1980 Retinoid inhibition of superoxide anion radical production by human polymorphonuclear leukocytes stimulated with tumor promoters. Biochem. Biophys. Res. Commun. 97:883-888.

35. Kensler, T. W., and M. A. Trush. 1981. Inhibition of phorbol-ester-stimulated chemiluminescence in human polymorphonuclear leukocytes by retinoic acid and 5,6 epoxyretinoic acid. Cancer Res. 41:216-222.

36. Hiramatsu, M., and L. Packer. 1990. Antioxidant activity of retinoids. Methods Enzymol. 190:273-280.

37. Das, N. P. 1989. Effects of vitamin A and its analogs on nonenzymatic lipid peroxidation in rat brain mitochondria. J. Neurochem. 52:585-588.

38. Samokyszyn, V. M., B. F. Sloane, K. V. Honn, and L. J. Marnett. 1984 Cooxidation of 13-cis-retinoic acid by prostaglandin $\mathrm{H}$ synthase. Biochem. Biophys. Res. Commun. 124:430-436.

39. Samokyszyn, V. M., and L. J. Marnett. 1987. Hydroperoxide-dependent cooxidation of 13-cis-retinoic acid by prostaglandin H synthase. J. Biol. Chem. 262:14119-14133.

40. Marnett, L. J. 1987. The involvement of peroxyl free radicals in tumor initiation and promotion. In Anticarcinogenesis and Radiation Protection. P. A. Cerutti, O. F. Nygaard, and M. G. Simic, editors. Plenum, New York. 71-80.

41. Samokyszyn, V. M., and L. J. Marnett. 1990. Inhibition of liver microsomal lipid peroxidation by 13-cis-retinoic acid. Free Radical Biol. Med. 8:491496.

42. Samokyszyn, V. M., and L. J. Marnett. 1990. Inhibition of microsomal lipid peroxidation by 13-cis retinoic acid. Methods Enzymol. 190:281-288.

43. Sporn, M. B., and A. B. Roberts. 1991. Interactions of retinoids and transforming growth factor $\beta$ in regulation of differentiation and proliferation. Mol. Endocrinol. 5:3-7.

44. Verma, A. K., and R. K. Boutwell. 1977. Vitamin A acid (retinoic acid), a potent inhibitor of 12-0-tetradecanoyl-phorbol-13-acetate-induced ornithine decarboxylase activity in mouse epidermis. Cancer Res. 37:2196-2201.

45. Cope, F. O., B. D. Howard, and R. K. Boutwell. 1986. The in vitro characterization of the inhibition of mouse brain protein kinase- $\mathrm{C}$ by retinoids and their receptors. Experientia (Basel). 42:1023-1027.

46. Nishizuka, Y. 1986. Studies and perspectives of protein kinase-C. Science (Wash. DC). 233:305-312.

47. Troll, W., G. Witz, B. Goldstein, D. Stone, and T. Sugimura. 1982. The 
role of free oxygen radicals in tumor promotion and carcinogenesis. Carcinogenesis. 7:593-597.

48. Troll, W., and R. Wiesner. 1985. The role of oxygen radicals as a possible mechanism of tumor promotion. Annu. Rev. Pharmacol. Toxicol. 25:509-528.

49. Zimmerman, R., and P. Cerutti. 1984. Active oxygen acts as a promoter of transformation in mouse embryo C3H/10T 1/2/ fibroblasts. Proc. Natl. Acad. Sci. USA. 81:2085-2087.

50. Slaga, T. J., V. Solanki, and M. Logani. 1983. Studies on the mechanism of action of antitumor promoting agents: suggestive evidence for the involvement of free radicals in promotion. In Radioprotectors and Anticarcinogens. O. Nygaard and M. G. Simic, editors. Academic Press, New York. 471-485.

51. Cerutti, P. A. 1985. Prooxidant states and tumor promotion. Science (Wash. DC). 227:375-381.

52. Birnboim, H. C. 1983. Importance of DNA strand-break damage in tumor promotion. In Radioprotectors and Anticarcinogens. O. Nygaard, and M. G. Simic, editors. Academic Press, New York. 539-556.

53. Chance, B., H. Sies, and A. Boveris. 1979. Hydroperoxide metabolism in mammalian organs. Physiol. Rev. 59:527-605.

54. Dixit, R., H. Mukhtar, and D. R. Bickers. 1983. Studies on the role of reactive oxygen species in mediating lipid peroxide formation in epidermal microsomes of rat skin. J. Invest. Dermatol. 81:369-375.

55. Parshad, R., W. G. Taylor, K. K. Sanford, R. F. Camalier, R. Gantt, and R. E. Tarone. 1980. Fluorescent light-induced chromosome damage in human IMR-90 fibroblasts. Role of hydrogen peroxide and related free radicals. Mutat. Res. 73:115-124.

56. Sanford, K. K., R. Parshad, and R. Gantt. 1986. Responses of human cells in culture to hydrogen peroxide and related free radicals generated by visible light: relationship to cancer susceptibility. In Free Radicals, Aging, and Degenerative Diseases. J. Johnson, editor. Alan R. Liss, New York. 373-394.

57. Parshad, R., and K. K. Sanford. 1977. Proliferative response of human diploid fibroblasts to intermittent light exposure. J. Cell. Physiol. 92:481-486.

58. Parshad, R., and K. K. Sanford. 1977. Intermittent exposure to fluorescent light extends lifespan of human diploid fibroblasts in culture. Nature (Lond.). 268:736-737.

59. Ames, B. N., and L. S. Gold. 1990. Chemical carcinogenesis: too many rodent carcinogens. Proc. Natl. Acad. Sci. USA. 87:7772-7776.

60. Ames, B. N., and L. S. Gold. 1991. Endogenous mutagens and the causes of aging and cancer. Mutat. Res. 250:3-16. 